\title{
Fusarium culmorum isolated from rhizosphere of wooly cupgrass (Eriochloa villosa) in Debrecen (East Hungary)
}

\author{
Tamás Tóth - Arnold Szilágyi \\ University of Debrecen, Faculty of Agricultural, Food Sciences and Enviromental Management, \\ Plant Protection Institute, Debrecen, Hungary \\ toth.tamas@agr.unideb.hu
}

\begin{abstract}
SUMMARY
Wooly cupgrass (Eriochloa villosa) is an East-Asian originated weed species and it has been spreaded worldwide by now. The first occurrence of this species in Hungary was observed and published in 2008 nearby Gesztely village (Borsod-Abaúj-Zemplén county, North-East Hungary) than in the summer of 2011 a significant population was discovered next to Debrecen city (Hajdu-Bihar county, East Hungary). In 2013 this weed was also reported from Szentborbás village, Somogy county (South-West Hungary). These observations of spreading and its biological features (production of stolons and large number of seeds, moreover herbicide tolerance) indicate that wooly cupgrass (E. villosa) has a great potential of invasiveness, so it may become a hazardous weed not only in Hungary but in all over the world.

The objective of this study was to identify the fungus which was isolated from wooly cupgrass (E. villosa) root residue samples which were collected after maize harvesting on arable land in late autumn, near Debrecen. The identification of the fungus based on morphological characters of colonies and the features of conidia developed on potato dextrose agar (PDA) plates. After the examination of axenic culture we revealed that the fungus from rhizosphere of wooly cupgrass was Fusarium culmorum. Pathogenicity and/or endophytic relationship between the fungus and wooly cupgrass is still uncertain so pathogenicity tests and reisolations from plants are in progress.
\end{abstract}

Keywords: Fusarium culmorum, Eriochloa villosa, wooly cupgrass, ERBVI, Fusarium spp.

\section{ÖSSZEFOGLALASS}

Az ázsiai gyapjúfü (Eriochloa villosa) egy Kelet-Ázsiai eredetü gyomnövény, mely gyors terjedése nyomán manapság már a világ számos pontján megtalálható. Magyarországon 2008-ban jelent meg az elsö cikk a felbukkanásáról Gesztely község határában (Borsod-AbaújZemplén megye), majd 2011 nyarán egy nagyobb populációját találták meg Debrecen (Hajdú-Bihar megye) közelében. 2013-ban ugyancsak fellelhetö volt Szentborbás község külterületén, Somogy megyében (Délnyugat-Magyarország). E megfigyelések a hazai terjedéséröl és a biológiai alaptulajdonságai (inda-képzés, nagy mennyiségü magprodukció, valamint herbicid-tolerancia) miatt megalapozottan kijelenthetö, hogy az ázsiai gyapjúfü (E. villosa) nagy inváziós potenciállal rendelkezik, igy veszélyes gyomfajként kell rá tekinteni Magyarországon és az egész világon egyaránt.

Jelen vizsgálataink célkitüzése annak a mikroszkópikus gombafajnak a meghatározása volt, melyet a Debrecen közelében elhelyezkedö (a kukorica betakaritását követöen a tarlón visszamaradt) ázsiai gyapjúfü gyökerek mintáiból, késö összel gyüjtöttünk és izoláltunk. Az izolált kórokozó pontos meghatározása érdekében telepmorfológiáját és az ivartalan spórák (konídiumok) tulajdonságait burgonya dextróz agar (PDA) táptalajon figyeltük meg. Az axénikus tenyészet eredmények azt mutatják, hogy az ázsiai gyapjúfü minták rhizoszférájából a Fusarium culmorum fajt identifikáltuk. A gomba patogenitása és vagy endofiton jellege az ázsiai gyapjúfü növényen még bizonytalan, a mesterséges inokulációs és a vegetatív növényi részekböl való izolálhatósági vizsgálataink folyamatban vannak.

Kulcsszavak: Fusarium culmorum, Eriochloa villosa, ázsiai gyapjúfü, ERBVI, Fusarium spp.

\section{INTRODUCTION}

The woolly cupgrass (Eriochloa villosa /Thunb./ Kunth) belongs to the group of well adaptable weed plant species. The distribution of the plant in the temperate zones of Asia, Caucasus, Russia's Far Eastern region, China, Iran, Japan, Korea, Taiwan and Vietnam is common (Tsvelev, 1984). In several states of the USA and Canada were also released. The species has been found in France, Ukraine, Romania and Hungary (Figure 1).

The first report of observation was made by $\mathrm{J}$. Madarász and P. Partosfalvi on the $5^{\text {th }}$ (Hungarian) National Weed Surveys in 2007. Partosfalvi et al. (2008) reported the occurence of woolly cupgrass near Gesztely village (North-East Hungary) in 2007.

The wooly cupgrass plants were also detected in Debrecen (East Hungary) on agricultural fields by Somogyi et al. (2011).
In 2013 a small population of this weed was reported from close to Szentborbás village (Somogy county, South-West Hungary), too (Takács et al., 2014).

The Hungarian climate provides good conditions for this recently appeared weed species. The most favourable conditions for colonization of wooly cupgrass are $10-11{ }^{\circ} \mathrm{C}$ in average annual temperature, $550-600 \mathrm{~mm}$ in average annual rainfall, and 5.5-6.5 soil pH (Fărcăşescu et al., 2008). The optimum germination temperature for most of the weeds is between $20-35^{\circ} \mathrm{C}$ (Bello et al., 2000). The germination of woolly cupgrass starts in mid-April in Hungary. The mass hatching period is followed by a second minor germination peak. Hence, the emergence fully extended, which makes it difficult to control. The ripening of grain yield starts in August and begin to achieve its distribution by animals and human activities. The woolly cupgrass belongs to $\mathrm{T} 4$ group of plants according to the Ujvárosi' weed plant-life-type classification system. 
Figure 1: Distribution of woolly cupgrass worldwide

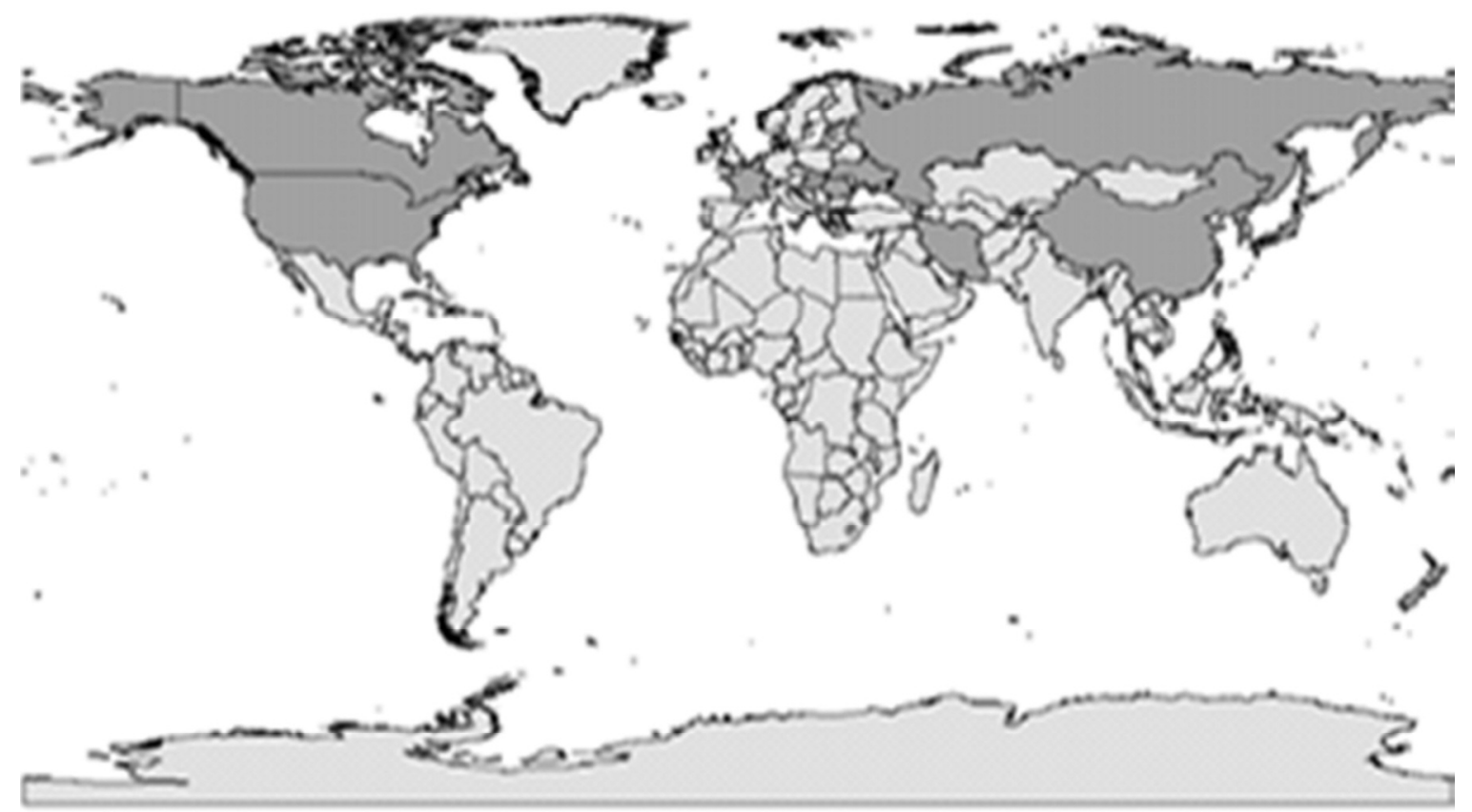

distribution based on published sources

Woolly cupgrass gets its name from the hairs covering many parts of the plant. It is a $30-200 \mathrm{~cm}$ high annual grass with dark green colour and densely hairy leaves that have a velvety feel. Only one edge of the leaf blade is typically crinkled, and the flowering branches are also one-sided (Figure 2). The woolly cupgrass impairs corn, sunflower, soybean cultures and stubble-fields.

According to the Systematic Mycology and Microbiology Laboratory Fungal Database (Farr and Rossman, 2016) there were 5 different fungal disease reported from wooly cupgrass (E. villosa), viz. Thanatephorus cucumeris (A.B. Frank) Donk from China (as 'Corticium sasakii /Shirai/ H. Matsumoto') and Taiwan, Pyricularia oryzae Cavara from Japan, Tolyposporium bullatum J. Schröt. from China, Uromyces eriochloae (Syd. \& P. Syd.) Syd., P. Syd. \& E. J. Butler from China and Japan, moreover Uromyces setariae-italicae Yoshino from Japan and Taiwan.
After we examined the morphological features of the colonies and conidia (asexual spores) the fungus proved as a Fusarium species on E. villosa.

Most of the species of Fusarium genus are plant pathogens. These fungi are usually soilborne, but they can be also dispersed by wind and rain. The different strains can occure in soil, on plant surfaces as saprotrophic microorganisms or insider plant pathogens as endophytes. The members of Fusarium genus are widespread all over the world and they can grow on numerous substrates (Leslie and Summerell, 2006). Fusarium species are able to overwinter mostly on infected plant debris as mycelia, or by chlamydospores. The penetration to healthy plants can occure on root tips (directly or through wounds) or at the time of the formation of lateral roots (Agrios, 2005).

Figure 2: Woolly cupgrass inflorescence branch, infesting a maize field
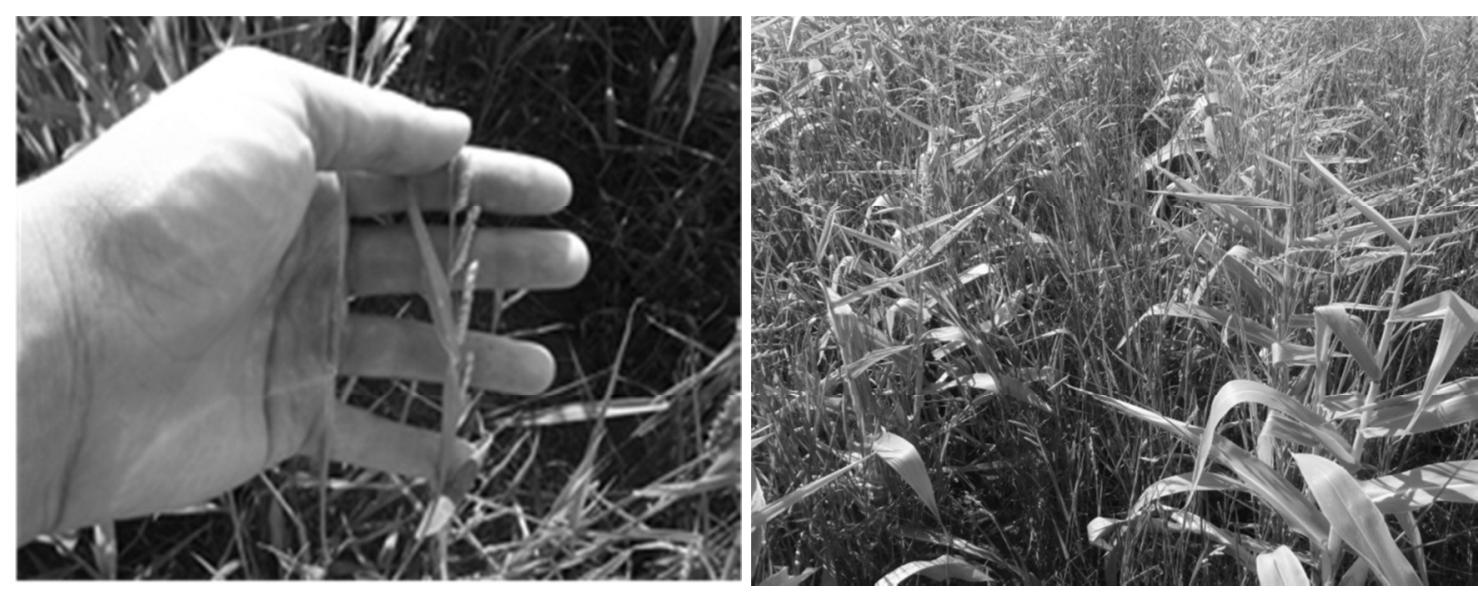
The diseases what the Fusarium species can cause on cultivated or weedy plants have wide range, which includes pre- and postemergence damping-off, head blight or foot rot symptoms. F. culmorum was also discovered and named as a common casual agent of different diseases on strawberries (Cieslinski and Lis, 1989), leeks (Koike et al., 2003), sorghums (Patil and Padule, 2000), hops (Sabo et al., 2002) and carnations (Broadhurst, 1990).

\section{MATERIAL AND METHODS}

The wooly cupgrass root samples infested with mycelia were collected on 2015. 11. 13. next to Debrecen (GPS coordinates: $47 ; 26 ; 29.2021 ; 34 ; 19.72$ ) at Hajdú-Bihar County (East Hungary) (Figure 3).
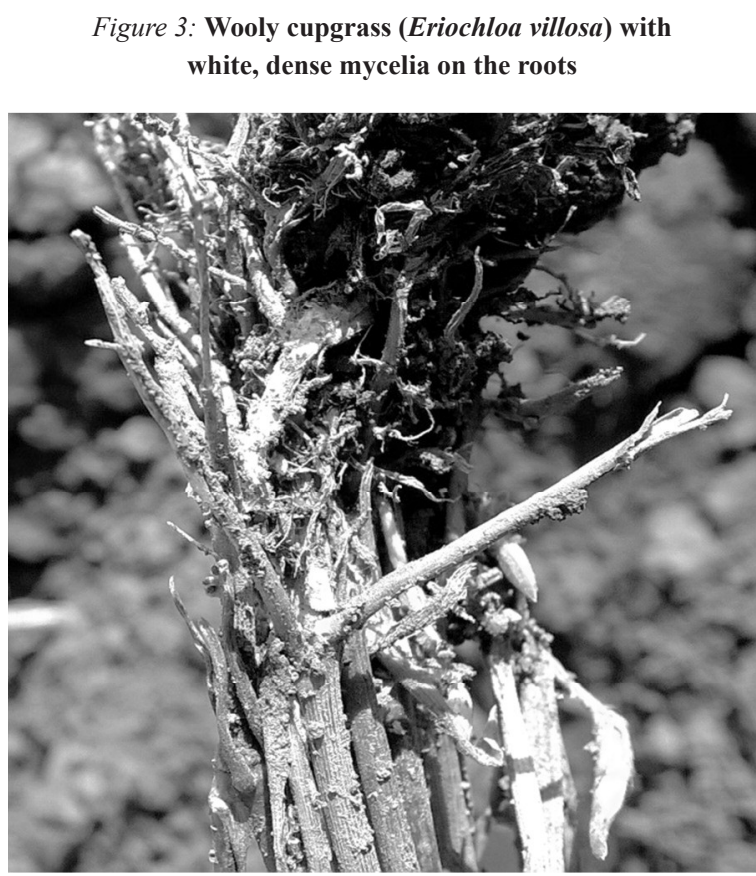

First roots of wooly cupgrass (E. villosa) were washed from soil with tapwater for 5 minutes. For isolation the species from infested plant debris were cut into $3 \mathrm{~cm}$ pieces and the surface of roots were sterilized in $1 \%$ chlorogen $\left(\mathrm{C}_{6} \mathrm{H}_{5} \mathrm{SO}_{2} \mathrm{NClNa} \cdot \mathrm{xH}_{2} \mathrm{O}\right)$ (Neomagnol) solution for 5 minutes and rinsed 3 times in sterile distilled water. After the surface-sterilization the samples were placed into moist chambers $(9 \mathrm{~cm}$ Petri dishes cointaining filter papers and moistened by sterile tapwater) for 7 days.

When mycelia appeared the fungus were transferred to potato dextrose agar (PDA) plates and incubated at $20^{\circ} \mathrm{C}$.

\section{Morphological identification}

The identification of fungus on wooly cupgrass roots were based on the morphology of asexual spores (macroconidia) under light microscope and the specifications of the colony. Conidia were photographed by Zeiss AxioCam MRc5 camera. The species was charaterized by mycelial growth rate, the pigmentation of the colony and the density of mycelia growing on potato dextrose agar (PDA) plates on the $5^{\text {th }}$ day. We studied these parameters to delimitate the Fusarium species according to Leslie and Summerell (2006).

\section{RESULTS AND DISCUSSION}

\section{Colony morphology of the fungus on wooly cupgrass roots}

The morphology of the colonies on potato dextrose agar (PDA) and the macroconidia on sporodochia were typical of those specifications which were described for Fusarium culmorum (Wm. G. Sm.) Sacc. by Leslie and Summerell (2006).

Fusarium culmorum is a rapid growing fungus (fill the plate within 5 days) and produces abundant sporodochia. Colour of colonies showed pale orange first and became dark brownish to reddish later. The examined strains formed red pigments in the agar and dense, white, aerial mycelia (Figure 4).

Figure 4: Colony morphology of Fusarium culmorum on PDA plate (A: front, B: reverse) on the $5^{\text {th }}$ days of transfer

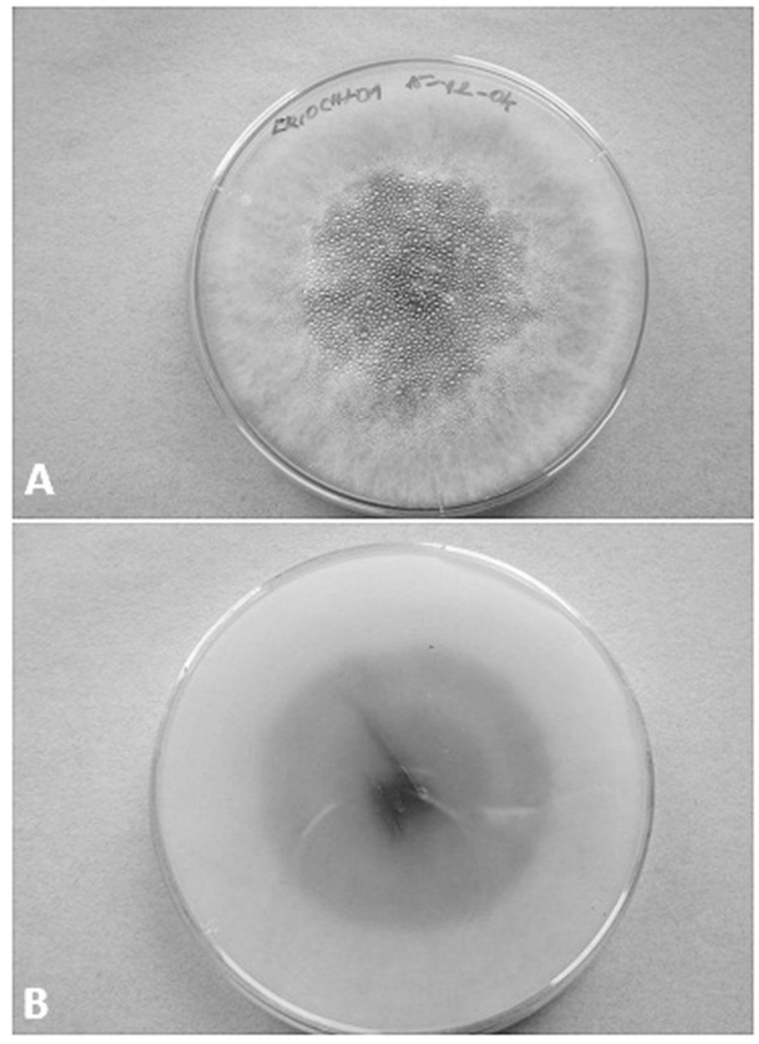

\section{Macroconidia}

The asexual spores under microscope were relatively short and stout (compared to other Fusarium species), and cell walls were thick. The macroconidia were the widest at midpoint, dorsal side were curved, but ventrally almost straight. The foot cells of the spores were rounded and blunt. Number of septa were 3, 4 or 5 (Figure 5). There were no microconidia observed.

It is important to highlight that off-season wooly cupgrass (E. villosa) root samples were collected during this survey and we couldn't see any disease symptoms except the white mycelia on the roots, which means that the isolated Fusarium culmorum may existed as a saprothrophic microbe in the rhizosphere of the weed. 
Figure 5: The short and stout asexual spores (macroconidia) of Fusarium culmorum

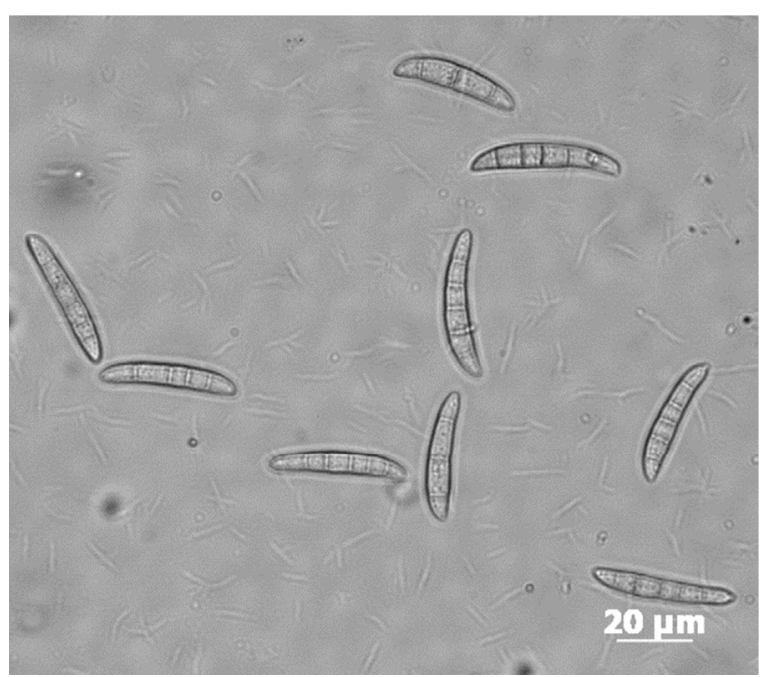

This observation also indicates the importance of clearing agricultural fields and edges from weeds, because these can serve as reservoirs and may contribute to survive pathogens.

\section{CONCLUSIONS}

Eriochloa villosa (wooly cupgrass) is an annual grass weed resulting serious losses, and the control is difficult and expensive. Its biological features (production of stolons and large number of seeds, herbicide tolerance) indicates that the effective control carried out only by combined elements of Integrated Pest Management (IPM) methods (chemical, cultural and mechanical). Until now there is no information about effective biocontrol opportunity against this invasive weed species.

The objective of this survey was to identify the fungus which was occured on the rhizosphere of wooly cupgrass (E. villosa) samples. It was concluded that the identified species was Fusarium culmorum. Traditional identification was made on the base of morphological properties of colony and characterisation of asexual spores (macroconidia).

As F. culmorum is a common plant pathogen and causes different diseases on important cultivated plants so it can't be used as a potential biocontrol agent against this hazardous weed species.

To our knowledge this is the first report on the occurence of Fusarium culmorum from wooly cupgrass (E. villosa) rhizosphere in Hungary. Pathogenicity and/or endophytic relationship between fungus and wooly cupgrass is still uncertain so pathogenicity tests and isolations from plants are in progress.

\section{REFERENCES}

Agrios, G. N. (2005): Plant pathology. $5^{\text {th }}$ ed. San Diego (CA) Elsevier Academic Press. Burlington. MA. US. 922.

Bello, I. A.-Hatterman-Valenti, H.-Owen, M. D. K. (2000): Factors affecting germination and seed production of Eriochoa villosa. Weed Science. 48: 749-754.

Broadhurst, P. G. (1990): Fusarium graminearum causing stub dieback of carnations in New Zealand. New Zealand Journal of Crop and Horticultural Science. 18: 137-140.

Cieslinski, G.-Lis, E. (1989): Studies on the infection of strawberry roots Fragaria grandiflora Duch. by fungi of the genus Fusarium in in vitro conditions. Fruit Science Reports. 16: 7-16.

Fărcășescu, A. M.-Arsene, G. G.-Neacşu, A. G. (2008): Eriochloa villosa (Thunb.) Khunt - a new invasive weed in Romania Journal of Plant Diseases and Protection. Special Issue. 21: 333-334.

Farr, D. F.-Rossman, A. Y. (2016): Fungal Databases, Systematic Mycology and Microbiology Laboratory, ARS, USDA. Retrieved April 20, 2016. http://nt.ars-grin.gov/fungaldatabases/

Koike, S. T.-Gordon, T. R.-Aegerter, B. J. (2003): Root and basal rot of leek caused by Fusarium culmorum in California. Plant Disease. 87: 601
Leslie, J. F.-Summerell, B. A. (2006): The Fusarium Laboratory Manual. Blackwell Professional. Ames. Iowa. USA.

Partosfalvi P.-Madarász J.-Dancza I. (2008): Az ázsiai gyapjúfú (Eriochloa villosa /Thunb./ Kunth) megjelenése Magyarországon. - Növényvédelem. 44: 297-304.

Patil, P. J.-Padule, D. N. (2000): Effects of grain mold fungi on seed germination and seedling vigor index of sorghum seeds var CSH-9 in western Maharashtra. Seed Research. 28: 190-192.

Sabo, J.-Duric, T.-Jasnic, S. (2002): Fusarium fungi as a pathogen causing hop wilt. Plant Protection Science. Special Issue 2. 38: 308-310.

Somogyi N.-Szabó L.-Dávid I. (2011): Az ázsiai gyapjúfü (Eriochloa villosa [Thunb.] Kunth) megjelenése Hajdú-Bihar megyében. Agrártudományi Közlemények. 11: 119-123.

Takács A.-Nagy T.-Molnár V. A. (2014): Három szórványos előfordulású, behurcolt pázsitfüfaj [Dasypyrum villosum (L.) Borbás, Eleusine indica (L.) Gaertn. és Eriochloa villosa (Thunb.) Kunth] új adatai a Dél-Dunántúlról. Apró közlemények - Kitaibelia. 19. 1: 173-176.

Tsvelev, N. N. (1984): Grasses of the Soviet Union. Vol II. (transl. Balkema, A. A., Russian translations series No. 8) Rotterdam. 1196. 